\title{
Alliance Orientation: Conceptualization, Measurement, and Impact on Market Performance
}

\author{
Destan Kandemir \\ Bilkent University, Turkey
}

\author{
Attila Yaprak \\ Wayne State University \\ S. Tamer Cavusgil \\ Michigan State University
}

Interfirm collaborations have inspired a rich literature in marketing and strategy during the past two decades. Building on this extant work, the authors developed a new construct, alliance orientation, and explored its influence on firms' alliance network performance and market performance. The authors drew on data collected from 182 U.S. firms with extensive experience in forming, developing, and managing strategic alliances in marketing, new product development, distribution, technology, and manufacturing projects. Using structural equations modeling, the authors demonstrate that alliance orientation significantly affects alliance network performance, which in turn enhances market performance. The findings also suggest that market turbulence exerts a significant moderating influence on the relationship between alliance orientation and alliance network performance, whereas the moderating role of technological turbulence on that relationship does not appear to be significant. The study provides evidence that firms' alliance orientations positively affect their performance in strengthening their alliance network relationships and in managing conflicts with their alliance partners.

Journal of the Academy of Marketing Science.

Volume 34, No. 3, pages 324-340.

DOI: 10.1177/0092070305285953

Copyright $\odot 2006$ by Academy of Marketing Science.
Keywords: alliance orientation; capabilities; alliance management; market orientation; organizational learning

Alliances, voluntary collaborative arrangements between firms that involve the exchange, sharing, and codevelopment of products, services, and knowledge have become a pervasive phenomenon in business today. As markets have grown increasingly fragmented and patterns of market growth and evolution have become increasingly influenced by the forces of globalization and the rapid diffusion of technology, nurturing and sustaining partnerships along the value delivery chain have become significant marketing skills in achieving market performance. Today, marketers relate to one another increasingly in the roles of suppliers, customers, collaborators, and competitors. Consequently, the issues of how firms form and nurture meaningful collaborative relationships, how they evolve and adapt to turbulent market environments, and how they manage value flows in such environments have become important questions that deserve increasing research attention (Day and Montgomery 1999).

Thus, a rich literature has evolved on these questions recently. This stream of work includes studies in strategy that focus on how firms learn, function, and evolve through alliances (Doz 1996), and those in organizational behavior, centering on how firms decide to enter alliances, 
choose appropriate partners, decide on appropriate structures for the alliances, and learn through the alliances as the relationships evolve over time (Gulati 1998). In the field of marketing, some studies have focused on the antecedents and consequences of collaborative relationships (Dwyer, Schurr, and Oh 1987; Jap and Ganesan 2000; Webster 1992), whereas others have linked the structure of alliances (horizontal vs. vertical) to knowledge sharing between partners (Rindfleisch and Moorman 2001) or collaborative performance (Dahlstrom, McNeilly, and Speh 1996). Other studies have attempted to explain the nature of governance in interfirm relationships, especially in buyer-seller contexts (Dwyer et al. 1987; Heide and John 1990; Narayandas and Rangan 2004) and explored the process of relationship development and maintenance (Lambe, Wittmann, and Spekman 2001). Still other studies have categorized alliances by the nature of their activities, such as comarketing (Bucklin and Sengupta 1993) or new product alliances (Rindfleisch and Moorman 2001; Sivadas and Dwyer 2000), and others have examined the impact of the symmetry of power between partners on the functionality of their relationship (Gundlach and Cadotte 1994) and the effectiveness of relational control mechanisms on alliance governance (Anderson and Narus 1990; Kumar, Scheer, and Steenkamp 1995; Morgan and Hunt 1994).

The findings of these studies would be more meaningful, however, if they were to account more comprehensively for how a firm might develop and nurture an alliance orientation, that is, a portfolio of scanning, coordination, and learning skills that are superior to those of its competitors, and how this might influence the firm's alliancerelated choices, behaviors, and outcomes, such as its market performance (Lambe, Spekman, and Hunt 2002). That is, a more complete understanding of firms' abilities in accumulating and sustaining skills in alliance scanning, alliance coordination, and learning from collaborative experiences should enhance our knowledge of the drivers of firms' organizational actions and the key ingredients of their organizational and market performance.

We have attempted to contribute to filling this void by advancing marketing knowledge in three directions. First, we conceptualized a new construct, alliance orientation, drawing from studies in market orientation (Jaworski and Kohli 1993; Narver and Slater 1990), organizational behavior (Teece, Pisano, and Shuen 1997), and strategy (Anand and Khanna 2000; Lambe et al. 2002). We argue that as firms enter into partnerships with growing frequency, they encounter new problems that emerge from the management of their alliance networks, and we empirically tested Gulati's (1998) and Anand and Khanna's (2000) argument that firms will strengthen their cooperative capabilities as they expand these experiences. Drawing from the market orientation literature (Jaworski and Kohli 1993; Narver and Slater 1990), we conceptualized alliance orientation as a firm's skill portfolio of superior capabilities that help it scan its environment for partnering opportunities, coordinate its alliance strategies, and learn from its alliance experiences. We developed a measure with which we gauged the effect of alliance orientation on a firm's alliance network performance and validated its various facets.

Second, we empirically investigated, at the strategic business unit level, the performance consequences of the alliance orientation of a firm. Because many activities influence firms' performance, we focused specifically on one of these: the interplay between alliance orientation and alliance network performance. In doing so, we argue that the effective allocation of managerial resources to a firm's alliance relationships is an important ingredient in achieving superior market performance, and we used multiple measures in gauging that performance.

Third, we introduced a conditional dimension, environmental turbulence, to our study of firms' alliance orientations and examined its performance implications. We believe that this addition provides deeper insight into how market and technological turbulence might moderate the relationship between alliance orientation and alliance network performance. If these moderating effects exist, a firm could reap potential benefits by adjusting the degree of its alliance orientation through the selective allocation of its capabilities and alliance activities. In sum, our study's contributions include developing a new measure of alliance competence, illustrating how alliance competency might affect market performance, and demonstrating the conditions under which this result might hold.

\section{CONCEPTUAL FOUNDATIONS}

\section{The Dynamic-Capabilities View}

The dynamic-capabilities view of firms provides a useful conceptual lens through which we understand sources of firms' competitive advantage and the processes through which firms build, integrate, and configure their strategic resources to effectively respond to market changes (Eisenhardt and Martin 2000; Leonard-Barton 1992; Teece et al. 1997). A principal tenet of this view is that those firms that are able to build dynamic capabilities such as responsiveness, flexibility, and/or innovativeness in their markets will outperform their rivals, similar to the resource-based view of firms, which argues that a firm's superior performance is a function of its resource-based advantages over its rivals (e.g., value, rarity, imperfect imitability, and imperfect substitutability). Nelson and Winter (1982) viewed dynamic capabilities as the collection of organizational and strategic routines by which firms achieve new resource configurations to match rapidly changing 
markets as they evolve in response to performance feedbacks (Eisenhardt and Martin 2000; Teece et al. 1997). Zollo and Winter (2002) underscored this view, arguing that dynamic capabilities arise from continuous collective learning exercised through organizational processes and a firm's systematic methods for revising its operating routines.

In this context, alliances could be viewed as a strategic option that firms can use to pool and deploy resources of partner firms to more effectively compete in the marketplace (Day 1995; Varadarajan and Cunningham 1995). It would then follow that to effectively manage the complexity embedded in alliance relationships, firms would need to possess unique portfolios of dynamic capabilities (Day 1995; Lambe et al. 2002). Given the presumed asymmetric distribution of alliance-driven capabilities of partner firms, a firm's skills in configuring and deploying these portfolios of capabilities, which we call alliance orientation, could enable it to outperform its rivals in many aspects of alliance management and thus could help yield superior market performance in its marketing efforts.

To some extent, this conceptualization of alliance orientation parallels the conceptualization of market orientation in marketing (Day 1994; Kohli and Jaworski 1990; Narver and Slater 1990). For example, in their study, Narver and Slater (1990) modeled market orientation as an organizational culture that enables a firm to develop capabilities in market intelligence and coordination of internal business processes to act quickly and effectively in response to intelligence collected from customers and other external stakeholders. Kohli and Jaworski (1990) viewed market orientation as a collection of activities, including market intelligence generation, dissemination, and taking action in response to market stimuli. Day (1994) viewed market orientation as an organizational capability that involves market information processing activities. In summary, the focus of market orientation is on creating superior customer value on the basis of the knowledge derived from customer and competitor analyses.

In light of these views, we suggest that a firm can benefit from its alliance relationships as learning sources. From this behavioral perspective, we view an alliance-oriented firm as one that places a high priority on present and prospective alliance relationships and has advanced its ability to (1) skillfully scan for and identify partnering opportunities in its markets, (2) coordinate its alliance activities capably, and (3) learn from its alliance experiences more proficiently than its competitors. Thus, we view alliance orientation as a higher order capability (i.e., a competency) that results from a firm's continuous improvement of its lower order capabilities (Lambe et al. 2002). Therefore, we conclude that a firm with a stronger alliance orientation will possess greater alliance-driving capabilities that will lead to a superior core competency relative to its competitors.

Although our conceptualization of alliance orientation is driven by the market orientation literature, understanding alliance orientation as a distinct combination of alliancedriven capabilities is consistent with studies in marketing and strategy. In marketing, for example, Lambe et al. (2002) proposed that alliance competence, which consists of alliance experience, alliance manager development capability, and partner identification propensity, is an important capability for firms that wish to use alliances to achieve superior competitive advantages in the marketplace. Scholars in strategy have also underscored the importance of effectively managing alliances but also drawn attention to the difficulties in assembling the capabilities necessary for proficient alliance management (Anand and Khanna 2000; Simonin 1997).

\section{Dimensions of Alliance Orientation}

In our study, alliance orientation is viewed as composed of three capabilities: (1) alliance scanning, (2) alliance coordination, and (3) alliance learning. We propose that alliance orientation will be stronger when a firm possesses higher degrees of each of these capabilities and is able to skillfully configure and deploy them.

Thus, in our view, alliance orientation exhibits several key characteristics. First, it is valuable; that is, its utility will not diminish with usage (Prahalad and Hamel 1990). Second, it is hard to imitate because the processes for developing alliance orientation are embedded in cognitive routines that cannot be observed by competitors ( $\mathrm{Li}$ and Calantone 1998). Third, it is immobile because these processes, created within a firm, cannot be purchased in the open market (Barney 1991). Finally, it is rare because these processes are not possessed by a large number of rivals (Eisenhardt and Martin 2000). We now provide a more detailed discussion of each of these capabilities.

Alliance scanning. Firms can lose competitive positional advantage if their existing resources and capabilities become obsolete because of the environmental uncertainty that surrounds them in their markets (Hite and Hesterly 2001). In these instances, firms that have mastered scanning for partnering opportunities can reposition themselves in competitive markets and maintain their current advantages or develop new advantages (Gulati 1999). Furthermore, firms that possess superior skills for alliance scanning can achieve first-mover advantages in bringing the best candidates into relationships (Day 1995; Varadarajan and Cunningham 1995). Geringer (1991) suggested that the specific partner chosen can influence the overall mix of available resources and skills, the operating policies and procedures, and the short- and long-term via- 
bility of an alliance. Thus, firms that are able to proactively scan for partnering opportunities may be able to identify partners with complementary resources and strategic compatibilities much more skillfully, a competency that is important in successfully integrating these capabilities into the firms' own routines from their partners (Lambe et al. 2002; Sarkar, Echambadi, Cavusgil, and Aulakh 2001; Weitz and Jap 1995). Therefore, we conceptualized alliance scanning as the extent to which a firm proactively monitors for and identifies partnering opportunities.

Alliance coordination. Lorenzoni and Lipparini (1999) argued that when firms strive to produce mutually beneficial strategic outcomes in alliance partnerships, coordination becomes a critical skill to leverage the unique alliance network environment, to combine respective resources available to them, and to generate new capabilities that might be required. Coordination enhances the ability of firms to share information, opportunities, and activities with their network partners such that the firms can now exploit their competitive advantages more completely (e.g., Anderson and Narus 1990; Jap 1999). Information sharing serves to enhance the mutual understanding of the strategy and synchronizes a firm's activities with those of its alliances so that effective planning and implementation become easier. Firms that have developed coordination capabilities find that they have more integrated strategies, more synchronized activities, and more timely and meaningful dissemination of knowledge across their network partners (Anderson and Narus 1990; Dwyer et al. 1987). We conceptualized this capability, alliance coordination, as the extent to which a firm systematically integrates strategies, synchronizes activities, and regularly disseminates knowledge across its alliances.

Alliance learning. Because alliance management is an ill-defined and complex process and the detailed interactions between the partners cannot be completely prespecified in a formal contract, it is important for a partnering firm to learn about managing its alliances effectively. Thus, a firm feels the need to build alliance learning capabilities by pursuing activities to accumulate and leverage alliance management know-how associated with its prior and ongoing alliance experiences (Anand and Khanna 2000). This type of alliance learning would require learning capabilities that include systematic information processing (Huber 1991; Sinkula 1994) and diffusion of learning effects across a firm's portfolio of network partners.

Thus, our view of alliance learning involves a firm's internalization of its direct experiences, successes, and failures with alliances (Lyles 1988; Simonin 1997) and the appropriation of this learning across its alliance network. For example, internalized information can lead to further alliance learning from observation and evaluation of the
FIGURE 1

Proposed Conceptual Framework

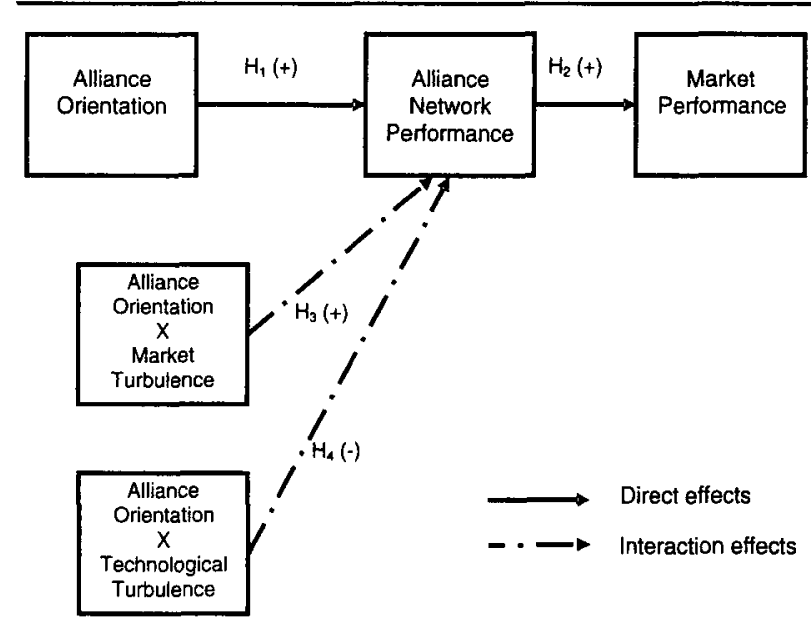

NOTE: $\mathrm{H}=$ Hypothesis.

decisions made on the basis of prior knowledge once it is interpreted through processes of sorting, classification, and simplification for coherent patterns (Day 1994; Huber 1991). This results in a shared understanding of alliance experience throughout an organization that can be leveraged in response to unforeseen contingencies in alliance interactions. Therefore, in harmony with the market orientation literature (Jaworski and Kohli 1993; Narver and Slater 1990) and studies in alliance management (Anand and Khanna 2000), we conceptualized alliance learning as the extent to which a firm acquires, interprets, and leverages alliance management know-how throughout its organizational network.

\section{PROPOSED FRAMEWORK AND HYPOTHESES}

As suggested in Figure 1, our proposed framework examines the relationships between a firm's alliance orientation and its alliance network performance and overall market performance. In this framework, alliance orientation is viewed as a key antecedent to alliance network performance. The framework postulates that alliance orientation will have a positive effect on alliance network performance, a mediating construct between alliance orientation and market performance, which in turn will enhance a firm's market performance. We further hypothesized that environmental turbulence will play a moderating role between alliance orientation and alliance network performance. We now discuss the rationale for each of these relationships and formulate hypotheses expressed from the perspective of a firm that forms and maintains alliance relationships. 


\section{Performance}

Although there is no consensus in the literature on the appropriate definition and possible measures of benefits achieved through alliances, these measures can be classified as measures of "common benefits" (Khanna 1998). A firm may also benefit from collaboration through an accretion to its "private benefits" (Khanna 1998). In this context, firm-specific performance refers to benefits that accrue to a focal firm from its application of learning to its own operations, whereas collaboration-specific performance refers to benefits that accrue collectively to all partners in the alliance (Khanna 1998). Although there is little empirical research on how firms successfully attain firmspecific performance through alliances, we do know that alliances realize both types of benefits (Khanna 1998). In our work, we focused on firm-specific performance and used two perceptual measures: (1) alliance network performance, describing that facet of performance derived from the pattern of interactions with a firm's network partners, and (2) overall market performance, derived from activities in a firm's markets not governed by the alliance.

\section{The Relationship Between Alliance Orientation and Alliance Network Performance}

We conceptualized alliance network performance as the strength of a firm's relationships with its key network partners and its ability to manage crises and conflicts with these partners satisfactorily. That is, a focal firm's alliance network performance reflects the overall perception of its attractiveness as an exchange partner to other firms within its alliance network. In this context, we refer to an "alliance network" as a portfolio of discrete, though related, bilateral alliances entered into by a firm. Because alliance orientation represents the degree to which alliance network management has been mastered as a business philosophy, we expected firms with strong alliance orientations to achieve enhanced alliance network performance on several grounds.

First, we expected alliance-oriented firms to proactively monitor their marketplaces, seek information from and about prospective partners, and sense market conditions and events more proficiently than their competitors. Because these firms are likely to have more reliable and timely information than their competitors about potential partners, especially about those with complementary resources or capabilities, they are likely to be attractive alliance partners themselves.

Second, the alliance coordination dimension of alliance orientation would imply the synchronization of alliance activities and strategies, and systematic knowledge transfer within a firm's alliance network. A firm that engages in coordinating activities is likely to realize several strategic benefits, such as superior access to resources, decreased supply and inventory costs, and the development of unique process technologies (Jap 1999). Because coordination will better enable a firm to leverage its unique alliance environment and gain access to resources and capabilities of network partners that otherwise would not be available, an alliance-oriented firm is likely to become a favorable partner for firms seeking new alliances.

Finally, because alliance orientation also emphasizes alliance-based learning, it is likely to enhance an allianceoriented firm's visibility and external recognition within alliance networks. Because firms that actively acquire, analyze, and leverage alliance management know-how can also internalize and refine their alliance management routines more readily than competitors (Gulati 1999), they will develop higher learning capabilities, put into place systems and structures that will simplify alliance management tasks, and thus possess stronger alliance relationships and become attractive potential network partners. Because alliance orientation will enhance a firm's ability to (1) scan alliance partnering opportunities, (2) achieve faster and coordinated decision making, (3) access certain kinds of exchanges that are particularly beneficial to it in mobilizing and leveraging resources of a network partner, and (4) enhance organizational learning and adaptation (Uzzi 1996), an alliance-oriented firm will create a competitive alliance network and stronger relationships than its non-alliance-oriented counterparts.

Hypothesis 1: A firm's alliance orientation will have a positive, direct impact on its alliance network performance.

\section{The Relationship Between Alliance Network Performance and Overall Market Performance}

We conceptualized market performance as the extent to which a firm achieves success in its existing businesses, products or markets, and in future positioning in its markets. Studies have reported on the positive effect that relational factors, such as strong ties, relational capital, and relationship quality can have on collaboration-specific performance (Aulakh, Kotabe, and Sahay 1996; Lambe et al. 2002). In line with these studies, we suggest that alliance network performance can make significant contributions to a focal firm's overall marketplace performance as a result of positive spillovers from its alliance experiences (Sarkar et al. 2001).

A focal firm creates a positional advantage in its alliance network on the basis of the quality of its relationships with network partners. In the development of strong relationships, a focal firm develops a better understanding of its partners' activities, resulting in superior exchange of tacit knowledge across organizational boundaries. Thus, it holds the advantages of high-quality information transfer 
and trust-based governance gained from strong relationships (Larson 1992; Uzzi 1996). Furthermore, strong relationships can act as a governance mechanism that promotes voluntary exchanges of resources and eliminates individual short-term interests (Uzzi 1996). Finally, establishing close contacts with network partners enables a focal firm to deal with conflicts and crises and develop joint problem-solving arrangements on the basis of rapid and explicit feedback from its partners. Because the focal firm is bestowed with benefits arising from the quality of its alliance relationships, the likelihood of its alliance formation between prospective partners will be enhanced (Chung, Singh, and Lee 2000; Tsai 2000).

Participation in networks enables firms to gather highquality information on one another. Furthermore, participation in such networks reduces contracting costs caused by informational asymmetries. The cost of opportunistic behavior in alliance networks tends to be higher because the damage to one's reputation influences not only the specific alliance in which a focal firm behaved opportunistically but all other current and potential partnerships as well (Anderson, Hakansson, and Johanson 1994; Gulati, Nohria, and Zaheer 2000). This participation incrementally promotes trust, thereby decreasing transaction costs by creating strong disincentives for opportunistic behavior (Larson 1992; Uzzi 1996). Thus, a focal firm with a greater degree of alliance network performance can signal that it is an attractive exchange partner to seek competitive advantages in the marketplace. It is also more likely to attract new partners with the potential to create synergies and profits. As a result, it will likely develop better marketplace positions of competitive advantage, such as reduced time to market, innovativeness, and responsiveness compared with its competitors.

Hypothesis 2: A firm's alliance network performance will have a positive, direct impact on its overall market performance.

\section{Moderating Effects of Environmental Turbulence}

We suggest that the linkage between alliance orientation and alliance network performance will be moderated by the environmental conditions within which a focal firm operates. For example, high turbulence may lessen a firm's ability to assess both the present and the future conditions in its environment and limit its ability to determine the potential impact of its decision making on current and future activities regarding alliance relationships. It is possible, therefore, that the impact of alliance orientation on a firm's alliance network performance will vary with the degree of turbulence in the firm's environment. In this study, we examined whether two forms of environmental turbulence, market and technological developments, will moderate the extent of the effect of alliance orientation on alliance network performance.

Market turbulence. The market orientation literature suggests that market turbulence is likely to arise from the heterogeneity and rapid changes in the composition of customers in the market and their preferences (Kohli and Jaworski 1990; Slater and Narver 1994). The level of turbulence in a focal firm's market is typically influenced by the rate of change in its downstream market and its network partners' share of this market (Heide and John 1990). Thus, a focal firm operating in a more turbulent market has to modify its products and approaches to market more readily to adapt to the changed preferences of its customers than firms that operate in more stable markets. Given the focal firm's heightened need for sequential, adaptive decision making, it is reasonable to expect that alliance orientation will be augmented in turbulent markets, because this will enable the firm to adjust to network partners more readily as a result of its interactions in multiple alliance relationships.

In highly turbulent markets, alliance orientation will involve the creation of new, situation-specific knowledge (Eisenhardt and Martin 2000). Alliance-oriented firms will monitor market developments more readily and will become more informed about partnering opportunities. This will allow them to adapt to their network partners faster. By coordinating activities in multiple relationships, alliance-oriented firms will be able to mobilize and leverage their resources embedded within the entire alliance network and take advantage of resources developed in connected relationships (Anderson et al. 1994).

Because the uncertainty in turbulent environments will increase causal ambiguity, it will be difficult for competitors to imitate resources or resource combinations in a timely manner (e.g., Eisenhardt and Martin 2000; Lippman and Rumelt 1982; Noda and Collis 2001). A firm will configure and apply its alliance-based capabilities in a dynamic manner to more effectively respond to the changing needs of its customers (Song, Dröge, Hanvanich, and Calantone 2005). Consequently, a firm with a higher level of alliance orientation will be more likely to be perceived as an attractive exchange partner to other firms. On the other hand, when the environment is relatively stable and predictable, competitors and prospective partners can clearly see which alliance-based activities and combinations of resources are valuable for building and maintaining successful alliance relationships; these can be imitated because time is not of the essence. Therefore, we argue that alliance orientation is more likely to be strongly related to alliance network performance in more turbulent rather than less turbulent markets. 
Hypothesis 3: The greater the market turbulence, the stronger the relationship between alliance orientation and alliance network performance.

Technological turbulence. Technological turbulence arises from changes in the underlying technologies of products or services and their rates of obsolescence. Changes in the standards or specifications of end products, components, or services contribute to technological turbulence. Thus, in industries in which the cycle of technological innovation or obsolescence is shorter and faster, it will be difficult for a focal firm to anticipate accurately the technical requirements in the alliance relationship. Although market turbulence increases the need for higher degrees of alliance orientation, in industries characterized by rapidly changing technologies, the role of alliance orientation in generating alliance network performance may be downplayed. If a firm focuses too much on its network partners and alliance activities, it may fail to fill the gap between current technological environmental requirements and its core technological capabilities. In such technologically turbulent environments, firms are more inclined to retain the flexibility to terminate alliance relationships and switch to partners with more appropriate technological competences (Heide and John 1990). As suggested by market orientation scholars (Kohli and Jaworski 1990; Slater and Narver 1994), many major product-class innovations are driven by research and development efforts outside the industries into which the innovations eventually assimilate rather than customer-oriented research. Consequently, the importance of developing knowledge about existing and potential partners, coordinating across alliance activities, and learning from alliance experiences may be hampered. Here, the main argument is that alliance orientation may not be as important as it is in technologically stable environments. Therefore, under conditions of technological turbulence, alliance orientation will be less of an influence on network performance for a focal firm.

Hypothesis 4: The greater the technological turbulence, the weaker the relationship between alliance orientation and alliance network performance.

\section{RESEARCH METHOD}

\section{Sample and Data Collection}

For this study, we drew from a database of 1,800 U.S.based corporations, with annual sales of over $\$ 25$ million, randomly selected from the CorpTech Directory of Technology Companies. The research setting included companies from a cross-section of industries chosen from the following Standard Industry Classification (SIC) codes: chemicals and allied products (SIC 28), industrial and machinery equipment (SIC 35), electronic and electric equipment (SIC 36), instruments and related products (SIC 38), computer and data processing (SIC 73), and engineering and management services (SIC 87). In the sample, the motives underlying a firm's entry into strategic alliances consisted of product development, marketing, distribution, manufacturing, supplier and customer sourcing, and technology development. For the purposes of this study, we defined a strategic alliance as a relatively enduring cooperative arrangement, either equity or project based, that involves interdependence and resource linkages among the partners and is formed to pursue common objectives linked to the corporate mission of each partner firm.

We conducted data collection in two stages. In the first stage, a cover letter accompanied by a statement of the research objectives was sent to the 1,800 U.S.-based companies requesting their participation in the study. In addition, the firms' CEOs were also asked to provide the names and contact details of two executives whom we could subsequently contact with the survey instrument. We asked for senior-level managers who were knowledgeable about the companies' strategic alliances and alliance-related procedures and activities. The CEOs also had the option of being key respondents. This was done in two waves, with the second wave of mailings following the first by 3 weeks.

Participating companies were promised an executive report summarizing the results of the study. Of these, 37 could not be contacted because of incorrect contact details, and 110 declined to participate for various reasons. Of the 1,800 companies contacted, 293 firms agreed to participate and provided the names and key informant details requested. Thus, the effective response rate in the first stage was 17.7 percent $(293$ of 1,653).

In the second stage, the mail survey, attached with a cover letter and a business reply envelope, was sent to the 293 executives who had agreed to participate in our study. Follow-up telephone calls and a second round of mailings took place 2 weeks after the first mailings. E-mail followups, when possible, were used. By the cutoff date, 184 companies had responded, of which 2 responses were unusable because of substantial missing data. The final response rate, defined as the number of usable responses received from the final sampling frame after accounting for refusals and employee mobility, was thus 65.9 percent (182 of 276). Key informants from the surveyed firms were mostly senior-level executives; vice presidents and above accounted for 95 percent of the respondents.

To assess nonresponse bias, we divided our data into two groups on the basis of the dates on which we received the completed surveys. The early responses consisted of the questionnaires received in the first mailing, before the followup phone calls. The late responses included the questionnaires received in the second mailing, after the follow-up 
phone calls. On the basis of a comparison of the averages of annual sales and the number of employees, $t$-tests between the mean responses of the early and the late respondents indicated no statistically significant differences at the .05 level (Armstrong and Overton 1977). Nonresponse bias did not appear to be present in the data.

\section{Measures}

We developed a structured survey instrument in several stages. Measurement of the constructs was accomplished via the use of both established and original scales. We followed the scale development and testing procedures suggested by Anderson and Gerbing (1988), Churchill (1979), and Fornell and Larcker (1981). First, we screened the literature to identify verified scale items to measure the factors we used in our work. For new scales (i.e., alliance orientation and alliance network performance), we developed measures using the framework proposed by Churchill. Constructs were defined, an item pool was generated, and the format of measurement was decided. A list of items that would be potentially useful as measures was developed from the literature. To establish face validity, we sought multiple items that would tap the domains of the constructs. For example, we reviewed the major conceptual literature on alliance management (Anand and Khanna 2000; Lambe et al. 2002) and market orientation (Jaworski and Kohli 1993; Narver and Slater 1990) to identify the underlying facets of alliance orientation. Research suggests that alliance management capabilities include specific firm activities, among which are those involved in learning about a firm's alliance network partners. Similarly, the market orientation literature suggests that market orientation consists of activities involved in learning about customers and competitors and includes the coordination efforts utilized in exploiting a company's resources. Drawing from this literature, we inferred that the three main components of alliance orientation would include alliance scanning, alliance learning, and alliance coordination activities.

We then submitted the scale measures to a small group of academics who have conducted research on alliances and/or strategic marketing. On the basis of their assessments, we dropped some statements and modified others. We pretested the draft questionnaire with several executives who had managed alliance relationships. The executives that participated in this preliminary stage were identified from the original CorpTech directory. We contacted these executives, informed them about the study, and requested interviews. A brief summary of the research project and the interview protocol was faxed or e-mailed to them in advance. The interviews, lasting an average of 1 hour, were conducted following a semistructured format. On the basis of their comments, we refined some items and ensured that the survey instrument was in an understandable and logical format. As a result of this measurement development process, we used three to nine statements to measure the constructs in the model.

Alliance orientation. We had conceptualized alliance orientation as a competency that tends to increase in magnitude as each of the three fundamental alliance-driven capabilities, alliance scanning, alliance coordination, and alliance learning, increases (Diamantopoulos and Winklhofer 2001; Jarvis, Mackenzie, and Podsakoff 2003). Because we had viewed alliance orientation as a composite of these three capabilities that required a second-order formative measure, we measured it as the overall mean score of these three capabilities. We developed the scales we used for measuring the dimensions of alliance orientation from the literature, because existing scales were unavailable.

Alliance scanning, which was a three-item reflective measure, was intended to capture the extent to which a firm proactively engaged in scanning for partnering opportunities, information acquisition, and collection about potential partners. Alliance coordination, which was a three-item reflective scale, assessed the extent to which a firm engaged in coordinating activities and strategies and in the sharing of knowledge across a portfolio of network partners. Alliance learning, which was a threeitem reflective scale, was intended to capture the extent to which an organization acquired, interpreted, and leveraged alliance management know-how. To measure these three dimensions of alliance orientation, we used a 5-point Likert-type scale ranging from strongly disagree (1) to strongly agree (5).

Alliance network performance. We developed new scales for measuring alliance network performance. These assessed the degree to which managers perceived the competitive strength of their firms' alliance networks, the strength of their relationships with key network partners, and their ability to manage crises and conflicts with their partners as satisfactory. Alliance network performance was intended to capture a firm's perceived ability to achieve its organizational objectives associated with its alliance network. We used a 5-point, Likert-type scale ranging from very unsatisfactory (1) to very satisfactory (5) to measure this construct.

Market performance. We adapted the measures we used for market performance from Gupta and Govindarajan (1984) and Venkatraman and Ramanujam (1986). These helped assess the success of a firm's products and programs in existing businesses and in those related to its future positioning. Three separate dimensions of firm performance were captured: sales growth, market share, and market development. Each was measured relative to the focal firm's competitors. We used a 5-point Likert-type scale ranging from much worse (1) to much better (5) to measure this construct. 
TABLE 1

Correlation Matrix for Measurement Scales

\begin{tabular}{|c|c|c|c|c|c|c|c|c|c|c|c|c|c|c|c|c|c|c|c|c|}
\hline Variable & $I$ & 2 & 3 & 4 & 5 & 6 & 7 & 8 & 9 & 10 & 11 & 12 & 13 & 14 & 15 & 16 & 17 & 18 & 19 & 20 \\
\hline 1. $\mathrm{ASCN}_{\mathrm{I}}$ & .000 & & & & & & & & & & & & & & & & & & & \\
\hline 2. $\mathrm{ASCN}_{2}$ & .643 & 1.000 & & & & & & & & & & & & & & & & & & \\
\hline 3. $\mathrm{ASCN}_{3}$ & .658 & .661 & 1.000 & & & & & & & & & & & & & & & & & \\
\hline 4. $\mathrm{ACRD}_{1}$ & .320 & .308 & .272 & 1.000 & & & & & & & & & & & & & & & & \\
\hline 5. $\mathrm{ACRD}_{2}$ & .289 & .305 & .274 & .689 & 1.000 & & & & & & & & & & & & & & & \\
\hline 6. $\mathrm{ACRD}_{3}$ & .177 & .175 & .138 & .565 & .531 & 1.000 & & & & & & & & & & & & & & \\
\hline 7. $\mathrm{ALRN}_{1}$ & .388 & .418 & .361 & .410 & .490 & .382 & 1.000 & & & & & & & & & & & & & \\
\hline 8. $\mathrm{ALRN}_{2}$ & .352 & .393 & .345 & .304 & .426 & .294 & .675 & 1.000 & & & & & & & & & & & & \\
\hline 9. $\mathrm{ALRN}_{3}$ & .306 & .300 & .282 & .298 & .318 & .370 & .498 & .405 & 1.000 & & & & & & & & & & & \\
\hline 10. $\mathrm{ANTP}_{1}$ & .385 & .261 & .316 & .351 & .292 & .218 & .310 & .260 & .134 & 1.000 & & & & & & & & & & \\
\hline 11. $\mathrm{ANTP}_{2}$ & .298 & .241 & .257 & .308 & .245 & .146 & .346 & .324 & .119 & .524 & 1.000 & & & & & & & & & \\
\hline 12. $\mathrm{ANTP}_{3}$ & .293 & .279 & .262 & .398 & .265 & .289 & .329 & .246 & .213 & .508 & .515 & 1.000 & & & & & & & & \\
\hline 13. $\mathrm{MKTP}_{1}$ & .103 & .099 & .008 & .065 & -.031 & .075 & .041 & .069 & .089 & .272 & .208 & .215 & 1.000 & & & & & & & \\
\hline 14. $\mathrm{MKTP}_{2}$ & .127 & .124 & .157 & .112 & .105 & .152 & .093 & .126 & .117 & .252 & .226 & .143 & .424 & 1.000 & & & & & & \\
\hline 15. $\mathrm{MKTP}_{3}$ & .219 & .148 & .202 & .069 & .019 & .105 & .040 & .086 & .194 & .296 & .148 & .185 & .428 & .498 & 3.000 & & & & & \\
\hline 16. $\mathrm{MTRB}_{1}$ & .036 & .117 & .058 & .086 & .059 & .088 & .163 & .161 & .109 & .148 & -.012 & .127 & .032 & .013 & .006 & 1.000 & & & & \\
\hline 17. $\mathrm{MTRB}_{2}$ & .127 & .147 & .131 & .182 & .142 & .069 & .240 & .151 & .085 & .108 & .065 & .105 & .037 & -.004 & -.044 & .587 & 1.000 & & & \\
\hline 18. $\mathrm{TTRB}_{1}$ & .111 & .099 & -.029 & .094 & .109 & .039 & .033 & .103 & .135 & .094 & -.064 & .090 & -.013 & -.105 & -.025 & .364 & .333 & 31.000 & & \\
\hline 19. $\operatorname{TTRB}_{2}$ & -.002 & -.004 & -.054 & .140 & .092 & .084 & .005 & .107 & .005 & .086 & -.032 & .081 & .009 & -.138 & $3-.099$ & .400 & .390 & 0.660 & 1.000 & \\
\hline 20. $\mathrm{TTRB}_{3}$ & .064 & .047 & .016 & .152 & .122 & .136 & .073 & 3.190 & .040 & .146 & .004 & .042 & -.071 & -.060 & -.002 & .471 & .341 & 1.632 & 2.661 & 1.000 \\
\hline$M$ & 3.77 & 3.56 & 3.79 & 2.63 & 2.54 & 2.31 & 3.17 & 3.09 & 3.49 & 3.39 & 3.69 & 3.68 & 3.32 & 3.42 & 3.29 & 3.02 & 2.79 & 4.01 & 3.19 & 3.15 \\
\hline$S D$ & 0.95 & 1.08 & 0.90 & 0.94 & 0.95 & 1.01 & 1.09 & 0.99 & 1.01 & 0.09 & 0.77 & 0.81 & 0.97 & 0.98 & 0.85 & 1.23 & 1.03 & 1.18 & 1.24 & 1.12 \\
\hline
\end{tabular}

NOTE: Italicized correlations are significant at $p<.05 . \mathrm{ASCN}=$ alliance scanning; $\mathrm{ACRD}=$ alliance coordination; $\mathrm{ALRN}=$ alliance learning; $\mathrm{ANTP}=$ alliance network performance; $\mathrm{MKTP}=$ market performance; $\mathrm{MTRB}=$ market turbulence; $\mathrm{TTRB}=$ technological turbulence.

Environmental turbulence. Measures for environmental turbulence, for both market and technology, were adapted from Germain, Dröge, and Daugherty (1994) and Jaworski and Kohli (1993). These measures were intended to measure the degree of dynamism and unpredictability in the market and the technological environments of a firm. We used a 5-point, Likert-type scale ranging from strongly disagree (1) to strongly agree (5) to measure each construct.

\section{ANALYSIS AND RESULTS}

\section{The Measurement Model}

We evaluated the psychometric properties of our measures using a confirmatory factor analysis (CFA) that combined each factor measured by reflective scales (Bagozzi, Yi, and Philips 1991; Gerbing and Anderson 1988). This resulted in a CFA that included seven factors: three dimensions of alliance orientation (e.g., alliance scanning, alliance coordination, and alliance learning), alliance network performance, market performance, market turbulence, and technological turbulence. The CFA was fitted using the maximum likelihood estimation procedure with the raw data as input in EQS 6.1 (Bentler 1995). Table 1 reports summary statistics and a correlation matrix for the measurement scales.
Composite reliability represents the shared variance among a set of observed variables that measure an underlying construct (Fornell and Larcker 1981). As shown in Appendix A, all constructs exhibited composite reliabilities above .7, indicating acceptable levels of reliability for each construct. In addition, all of the coefficient $\alpha$ values exceeded the threshold value of .7 recommended by Nunnally (1978), suggesting for each of the constructs a reasonable degree of internal consistency between the corresponding indicators (see Appendix A). Furthermore, all the factor loadings were statistically significant $(p<.01)$, which provided evidence of convergent validity (Bagozzi et al. 1991). Table 2 presents key results of the CFA.

Measures of overall fit evaluate how well a CFA model reproduces the covariance matrix of the observed variables. The chi-square test for our theoretical variables was not statistically significant, $\chi^{2}(149)=174.61, p>.05$. The Bentler-Bonett nonnormed fit index (NNFI), the comparative fit index (CFI), Bollen's incremental fit index (IFI), and the root mean square error of approximation (RMSEA) indicated a good fit with the hypothesized measurement model $(\mathrm{NNFI}=.98, \mathrm{NFI}=.89, \mathrm{CFI}=.98, \mathrm{IFI}=.98$, and RMSEA = .03; Hu and Bentler 1999; Table 2).

Discriminant validity was examined by calculating the shared variance between all possible pairs of constructs, verifying that they were lower than the average variance extracted for the individual constructs (Fornell and Larcker 1981). The highest level of shared variance between 
TABLE 2

Results of the Confirmatory Factor Analysis

\begin{tabular}{|c|c|c|}
\hline $\begin{array}{l}\text { Construct and } \\
\text { Measurement ltems }\end{array}$ & $\begin{array}{l}\text { Standardized } \\
\text { Loading }\end{array}$ & $\mathrm{t}$ Value $^{\mathrm{a}}$ \\
\hline \multicolumn{3}{|l|}{ Alliance scanning (ASCN) } \\
\hline $\mathrm{ASCN}_{1}$ & .81 & 12.21 \\
\hline $\mathrm{ASCN}_{2}$ & .81 & 12.17 \\
\hline $\mathrm{ASCN}_{3}$ & .81 & 12.23 \\
\hline Average variance extracted & $65.6 \%$ & \\
\hline Highest shared variance & $31 \%$ & \\
\hline \multicolumn{3}{|l|}{ Alliance coordination (ACRD) } \\
\hline $\mathrm{ACRD}_{1}$ & .84 & 12.59 \\
\hline $\mathrm{ACRD}_{2}$ & .82 & 12.28 \\
\hline $\mathrm{ACRD}_{3}$ & .66 & 9.21 \\
\hline Average variance extracted & $60.5 \%$ & \\
\hline Highest shared variance & $37 \%$ & \\
\hline \multicolumn{3}{|l|}{ Alliance learning (ALRN) } \\
\hline $\mathrm{ALRN}_{1}$ & .90 & 13.68 \\
\hline $\operatorname{ALRN}_{2}$ & .74 & 10.76 \\
\hline $\mathrm{ALRN}_{3}$ & .56 & 7.61 \\
\hline Average variance extracted & $55.7 \%$ & \\
\hline Highest shared variance & $37 \%$ & \\
\hline \multicolumn{3}{|c|}{ Alliance network performance (ANTP) } \\
\hline $\mathrm{ANTP}_{1}$ & .76 & 10.48 \\
\hline $\mathrm{ANTP}_{2}$ & .70 & 9.48 \\
\hline $\mathrm{ANTP}_{3}$ & .70 & 9.61 \\
\hline Average variance extracted & $51.9 \%$ & \\
\hline Highest shared variance & $27 \%$ & \\
\hline \multicolumn{3}{|l|}{ Market performance (MKTP) } \\
\hline $\mathrm{MKTP}_{1}$ & .60 & 7.38 \\
\hline $\mathrm{MKTP}_{2}$ & .69 & 8.45 \\
\hline $\mathrm{MKTP}_{3}$ & .72 & 8.80 \\
\hline Average variance extracted & $45.2 \%$ & \\
\hline Highest shared variance & $21 \%$ & \\
\hline \multicolumn{3}{|l|}{ Market turbulence (MTRB) } \\
\hline MTRB $_{1}$ & .81 & 10.24 \\
\hline $\mathrm{MTRB}_{2}$ & .71 & 9.11 \\
\hline Average variance extracted & $58 \%$ & \\
\hline Highest shared variance & $40 \%$ & \\
\hline \multicolumn{3}{|l|}{ Technological turbulence (TTRB) } \\
\hline $\operatorname{TTRB}_{1}$ & .78 & 11.62 \\
\hline $\mathrm{TTRB}_{2}$ & .84 & 12.96 \\
\hline $\mathrm{TTRB}_{3}$ & .82 & 12.43 \\
\hline Average variance extracted & $66.2 \%$ & \\
\hline Highest shared variance & $40 \%$ & \\
\hline
\end{tabular}

NOTE: Model fit statistics: $\chi^{2}(149)=174.61, p>.05 ;$ nonnormed fit index $=.98$, comparative fit index $=.98$, incremental fit index $=.98$, root mean square error of approximation $=.03$ ( $90 \%$ confidence interval .00 to .05 ).

a. The $t$ values from the unstandardized solution.

any pair of constructs was 40 percent (shared variance was equal to the squared correlation between the constructs). The average variances extracted ranged between 66.2 and 45.2 percent. These results showed that the average variance extracted by the measure of each factor was larger than the squared correlation of that factor's measure with all measures of other factors in the model (see Table 2). Given these values, we concluded that all the factors in the measurement model possessed strong discriminant validity. In light of this evaluation, we were able to conclude that all factors in the measurement model possessed both convergent and discriminant validity and that the CFA model fit the data adequately. On the basis of the evaluation of the measurement model, we selected a set of three items for all constructs, except for the market turbulence construct. Appendix A details the constructs, retained items, and associated reliabilities.

Subsequent to the assessment of convergent and discriminant validity of our constructs, we addressed how we might be able to consolidate the alliance orientation dimensions into a second-order construct. Diamantopoulos and Winklhofer $(2001: 274)$ argued that reflective specifications of latent variables often mistakenly prevail in the marketing literature. In reflective specifications, second-order constructs are assumed to cause their dimensions rather than being caused by them. Consequently, dimensions are viewed as strongly correlated and interchangeable facets of the focal construct (Bollen and Lennox 1991). Formative specifications view a secondorder construct as being caused by its dimensions. Dimensions that need not be highly correlated with one another define it. Accordingly, we conceptualized alliance orientation as a second-order formative construct represented by its alliance scanning, alliance coordination, and alliance learning dimensions. Because a firm may well score high on its alliance scanning activities while scoring low on its alliance coordination activities, we adopted a formative measurement approach to capture the meaning of alliance orientation (cf. Bollen 1989).

In addition, we tested the properties of our hierarchical measurement model against our first-order measurement model. The hierarchical measurement model considered alliance scanning, alliance coordination, and alliance learning as first-order dimensions of alliance orientation, which was a second-order reflective measure. That is, alliance orientation was assumed to cause its three dimensions rather than being caused by them. The second-order model produced a chi-square value of 186.31 with 157 degrees of freedom $(p>.05)$, with NNFI $=.97, \mathrm{CFI}=.98$, $\mathrm{IFI}=.98$, and RMSEA $=.03$. Although the second-order measurement model yielded similar fit indexes, the firstorder measurement model provided a better chi-square value $\left(\Delta \chi^{2}=11.71, \Delta d f=8\right.$; see Table 2). Thus, we concluded that the model in which alliance orientation was represented as a second-order reflective measure was not superior to the first-order model.

\section{Common Method Bias}

We used a CFA approach to Harman's one-factor test to test for potential common method bias (cf. Korsgaard and Roberson 1995; Mossholder, Bennett, Kemery, and Wesolowski 1998). If common method variance (CMV) were a serious threat to the analysis and interpretation of 
TABLE 3

Results of Hypothesis Testing

\begin{tabular}{|c|c|c|c|c|}
\hline \multirow[b]{2}{*}{$\begin{array}{l}\text { Independent } \\
\text { Variable }\end{array}$} & \multicolumn{2}{|c|}{ Dependent Variables } & \multirow[b]{2}{*}{ Hypothesis } & \multirow[b]{2}{*}{ Conclusion } \\
\hline & $\begin{array}{c}\text { Alliance } \\
\text { Network } \\
\text { Performance }\end{array}$ & $\begin{array}{c}\text { Market } \\
\text { Performance }\end{array}$ & & \\
\hline Alliance orientation & $.61^{* *}(7.28)$ & & 1 & Supported \\
\hline Alliance network performance & & $.46^{* *}(4.86)$ & 2 & Supported \\
\hline Alliance Orientation $\times$ Market Turbulence & $.26^{*}(1.89)$ & & 3 & Supported \\
\hline Alliance Orientation $\times$ Technological Turbulence & $-.14^{\mathrm{a}}(-1.08)$ & & 4 & Not supported \\
\hline Market turbulence & $.04^{\mathrm{a}}(0.33)$ & & & \\
\hline Technological turbulence & $-.06^{\mathrm{a}}(-0.54)$ & & & \\
\hline Squared multiple correlation & .42 & .21 & & \\
\hline
\end{tabular}

NOTE: Values in parentheses are $t$ values. Model fit statistics: $\chi^{2}(11)=18.09, p>.05 ;$ nonnormed fit index $=.92$, comparative fit index $=.96$, incremental fit index $=.96$, root mean square error of approximation $=.06(90 \%$ confidence interval .00 to .11$)$.

a. Nonsignificant.

${ }^{*} p<.05 .{ }^{* *} p<.01$.

the data, a single latent factor would account for all the manifest variables (Podsakoff, MacKenzie, Lee, and Podsakoff 2003). It should be noted that this is a diagnostic technique for assessing the extent to which CMV may pose a serious threat. The single-factor model yielded $\chi^{2}(170)=923.64$, compared with $\chi^{2}(149)=174.61$ for the measurement model that included seven factors; the fit was worse in the one-dimensional model than it was in the measurement model. A worse fit for the single-factor model suggests that one general factor did not account for the majority of the covariance among the measures in this study.

\section{Hypothesis Testing}

The hypothesized model was estimated by using structural equation modeling, with the EQS 6.1 program (see Figure 1). Our moderating effect analysis followed the method suggested by Mathieu, Tanenbaum, and Salas (1992). This procedure is described in Appendix B.

The results of the hypothesis testing are provided in Table 3, along with parameter estimates, their corresponding $t$ values, and the fit statistics. As reported in Table 3 , the chi-square test was not statistically significant, $\chi^{2}(11)=$ $18.09, p>.05$. The scores we achieved for the NNFI, the CFI, the IFI, and the RMSEA showed that the hypothesized model had good fit with the data $(\mathrm{NNFI}=.92, \mathrm{CFI}=$ $.96, \mathrm{IFI}=.96, \mathrm{RMSEA}=.06$ ). Table 3 shows the results of our hypothesis tests. Specifically, we found alliance orientation to be positively associated with alliance network performance $(\beta=.61, p<.01)$, supporting Hypothesis 1 . We also found alliance network performance to have a positive direct effect on market performance $(\beta=.46, p<$ .01 ), supporting Hypothesis 2.

As reported in Table 3, we found the product term related to market turbulence to be positively associated with alliance network performance $(\beta=.26, p<.05)$, supporting Hypothesis 3 . However, the product term related to technological turbulence did not show a significant $t$ value; we were therefore unable to support Hypothesis 4. The sign of this parameter was negative $(\beta=-.14, p>.05)$, as we had hypothesized, suggesting that technological turbulence should weaken the relationship between alliance orientation and alliance network performance. Furthermore, the direct effects of market turbulence and technological turbulence on alliance network performance were not significant. On the basis of these findings, we concluded that although market turbulence plays a significant moderating role between alliance orientation and alliance network performance, the role of technological turbulence in this context remains uncertain.

\section{The Mediating Effect of Alliance Network Performance}

Although developing the hypothesized model, we argued for positioning alliance network performance as a mediating variable. This hypothesized model allowed no direct path from alliance orientation to market performance, which implied a central nomological status for alliance network performance. To explore this mediating role, we followed the procedures described by Baron and Kenny (1986) and tested three structural models using EQS 6.1.

Model 1 examined the effects of our independent variables (i.e., alliance orientation, Alliance Orientation $x$ Market Turbulence, Alliance Orientation $\times$ Technological Turbulence, market turbulence, and technological turbulence) on the mediator variable (i.e., alliance network performance). Model 2 examined the effects of these independent variables on the dependent variable (i.e., market performance). Finally, Model 3 examined the effects of 
TABLE 4

Results for the Mediating Effect of Alliance Network Performance

\begin{tabular}{|c|c|c|c|}
\hline \multirow[b]{2}{*}{ Independent Variable } & \multicolumn{3}{|c|}{ Dependent Variables } \\
\hline & $\begin{array}{c}\text { Model 1: Alliance } \\
\text { Network Performance }\end{array}$ & $\begin{array}{c}\text { Model 2: Market } \\
\text { Performance }\end{array}$ & $\begin{array}{c}\text { Model 3: Market } \\
\text { Performance }\end{array}$ \\
\hline Alliance orientation & $.61^{* *}(7.28)$ & $.26 * *(2.68)$ & $-.03^{\mathrm{a}}(-0.24)$ \\
\hline Alliance network performance & & & $.49 * *(3.57)$ \\
\hline Alliance Orientation $\times$ Market Turbulence & $.25 *(1.828)$ & $.19^{\mathrm{a}} \quad(1.21)$ & $.11^{\mathrm{a}} \quad(0.72)$ \\
\hline Alliance Orientation $\times$ Technological Turbulence & $-.15^{\mathrm{a}}(-1.11)$ & $-.03^{\mathrm{a}}(-0.18)$ & $.02^{\mathrm{a}} \quad(0.14)$ \\
\hline Market turbulence & $.04^{\mathrm{a}} \quad(0.31)$ & $.03^{\mathrm{a}} \quad(0.21)$ & $.01^{\mathrm{a}} \quad(0.09)$ \\
\hline Technological turbulence & $-.04^{\mathrm{a}}(-0.37)$ & $-.18^{\mathrm{a}}(-1.38)$ & $-.17^{\mathrm{a}}(-1.30)$ \\
\hline Squared multiple correlation & .42 & .12 & .247 \\
\hline$\chi^{2}$ & 13.49 & 13.49 & 17.08 \\
\hline$d f$ & 6 & 6 & 8 \\
\hline$p$ & $>.01$ & $>.01$ & $>.01$ \\
\hline NNFI & .87 & .82 & .86 \\
\hline CFI & .95 & .93 & .95 \\
\hline IFI & .95 & .93 & .95 \\
\hline RMSEA & $.08(90 \% \mathrm{Cl}=.02$ to .14$)$ & $.08(90 \% \mathrm{CI}=.02-.14)$ & $.08(90 \% \mathrm{CI}=.02-.14)$ \\
\hline
\end{tabular}

NOTE: Values in parentheses are $t$ values. NNFI = nonnormed fit index; CFI = comparative fit index; IFI = incremental fit index; RMSEA = root mean square error of approximation; $\mathrm{CI}=$ confidence interval.

a. Nonsignificant.

${ }^{*} p<.05 .{ }^{* *} p<.01$.

our independent variables and our mediating variable (i.e., alliance network performance) on our dependent variable (i.e., market performance).

Models 1 and 2 sought to demonstrate that the independent variables affected the mediating variable and the dependent variable, respectively. Model 3 sought to establish that the mediating variable affected the dependent variable, even when the independent variables were controlled for. The requirements for establishing mediation were as follows: the independent variables had to affect the mediator in Model 1 and the dependent variable in Model 2 . The mediating variable had to affect the dependent variable in Model 3. Perfect mediation held if the independent variables had no effect when the mediator was controlled.

Major parameter estimates and fit statistics of the structural models are presented in Table 4 . We encountered no problems in estimation and achieved convergence without any boundary conditions. We used the estimates of the path coefficients to examine the mediating effect of alliance network performance. Of the independent variables, alliance orientation $(\beta=.61, S E=.09, p<.01)$ and Alliance Orientation $\times$ Market Turbulence $(\beta=.25, S E=.14$, $p<.05$ ) had significant, direct effects on alliance network performance (Model 1, Table 4). Consequently, we examined the effects of the independent variables on market performance and obtained a positive and significant effect for alliance orientation $(\beta=.26, S E=.11, p<.01 ;$ Model 2, Table 4). Model 3 , which included the paths to market performance from the mediator and the independent variables, also yielded significant and positive effects for alliance network performance only $(\beta=.49, S E=.14, p<.01$;
Table 4). The mediated effect $(.61 \times .49)$ was statistically significant (the approximate standard error was .09). We could therefore conclude that alliance network performance fully mediated the relationship between alliance orientation and market performance.

\section{DISCUSSI ON}

\section{Alliance Orientation}

The findings provide support for our proposed conceptualization of alliance orientation as a critical source of competitive advantage and its measurement as a composite construct. In this context, the individual dimensions of alliance orientation appear to be distinctive, yet related, capabilities associated with superior alliance management. In addition, we show that alliance orientation has a direct effect on alliance network performance as well as an indirect effect on market performance.

The alliance orientation construct and the scale with which we measure it offer important implications for theory development as well as practical guidance on how firms might go about developing this competency for superior alliance management. Firms that demonstrate enhanced alliance capabilities tend to be those with more effective skills in scanning, coordinating, and learning from alliances. These skills appear to lead them to manage their alliance networks more capably, thus achieving superior network, as well as market, performance. 
It would follow that senior managers ought to dedicate sufficient resources to cultivating scanning, coordination, and learning traditions within their firms. They can, in addition, help create organizational cultures that value interfirm collaboration. This would suggest that structural changes, including the appointment of "corporate alliance" or "corporate knowledge" officers, may be necessary. Their responsibilities might include the dissemination of learning from the many collaborative ventures throughout the organization.

\section{The Role of Alliance Network Performance}

Our findings also suggest that alliance orientation can produce favorable market performance, but only indirectly, with alliance network performance mediating the relationship between alliance orientation and market performance. This implies that superior marketplace performance may be more a function of how well ae firm extracts alliance-related benefits from its partnerships. The mere existence of alliance-promoting activities such as scanning and coordinating does not appear to be sufficient for favorable firm outcomes. Tangible fruits of collaboration must be derived by the entire network of collaborators for firm-level benefits to be accrued. These favorable network outcomes include competitive strength, formidable relationships, and effective crisis management. Those firms that are particularly adept at producing these gains from their partnerships will outperform others that fail to derive collaborative gains. These findings imply that managers need to continuously reconfigure their networks to achieve the most proficient collaborative routes to market performance.

\section{The Moderating influence of Environmental Turbulence}

Our empirical findings also confirm that the degree of uncertainty and the pace of change in customer demand and preferences do moderate the relationship between alliance orientation and alliance network performance. Specifically, a firm's alliance orientation appears to take on greater significance under more turbulent customer environments, paving the way for superior alliance network performance. This is plausible considering that one of the underlying motivations for collaborative ventures is risk reduction. To the extent the market environment poses challenges for an individual firm, managers may then resort to interfirm collaborative projects to combat them. Conversely, a relatively stable market environment may give managers a false sense of confidence that they can act unilaterally in responding to opportunities and challenges.

Unlike the role of market turbulence, the results fail to confirm a significant moderating role for technological uncertainty in influencing the relationship between alliance orientation and alliance network performance. Combined, these findings reflect mixed signals about the role of environmental turbulence in affecting the relationship between alliance orientation and alliance network performance. These mixed findings could be due to the particular operationalization of the technological turbulence construct, misspecification of the variables, or simply a misinterpretation of technological turbulence by our sample respondents. It is also possible, of course, that as our findings suggest, technological turbulence in a firm's environment may not be as relevant in the development and nurturing by the firm of its portfolio of skills, which we have labeled alliance orientation, or its relational skills, such as trust, commitment, forbearance and reciprocity between the firm and its partners. Finally, it can also be argued that alliance orientation may assume greater importance in technologically turbulent environments. For example, the timely introduction of new products to replace obsolete products may become crucial to firm success (Wind and Mahajan 1997). In these situations, a firm may place more emphasis on building stronger and integrated relation- ships with its alliance partners.

Overall, the study demonstrates that firms that are proactive in developing alliance-oriented skills are more likely to achieve greater marketplace performance. Although many firms engage in a variety of collaborative arrangements today, those that approach them proactively are more likely to derive superior competitive advantage. This appears to be a function of management's concerted efforts in (1) acquiring new skills, such as scanning the environment for prospective partners and partnership opportunities; (2) coordinating across alliances to maximize cross-fertilization, cross-learning, and other synergistic gains; and (3) programmatically appropriating these gains across a firm's alliance network. These skills, which we compose into a construct we name alliance orientation, appear to yield a positive effect on a firm's alliance network performance. Alliance orientation in turn appears to enhance a firm's market performance in terms of its sales growth, market share growth, and market development.

\section{Limitations and Directions for Future Research}

As interfirm collaborations become increasingly pervasive, firms are compelled to develop and sustain skill portfolios that yield superior performance and enduring competitiveness. In this study, we conceptualized and operationalized one such portfolio, alliance orientation, and empirically assessed its impact on market performance through a mediating construct we labeled alliance network performance. We view alliance orientation, akin to market orientation, as a proactive approach to the development and nurturing of partnering skills by firms. Contributing to alliance orientation are such skills as partner 
scanning, systematic coordination of activities across network partners, and continuous learning from alliance experiences. These findings advance knowledge of marketing-related and other types of collaborative ventures.

Several limitations of the study give rise to the desirability of future work on this topic. First, longitudinal studies might explore how dynamic changes in the config- uration of alliance orientation skills might affect firm-specific performance as a firm evolves organically and in response to environmental changes. In this context, the changing contributions to performance outcomes of collaboration-specific and firm-specific skill portfolios over time, and in response to environmental changes, could deepen our understanding of this relationship. Second, we encourage other scholars to add learning constructs into the model and study the affect of the dynamics of learning among collaborating partners on market performance. For example, absorptive capacity has been shown to be an important skill in acquiring and internalizing tacit resources and capabilities from a firm's partners that in turn might influence the collaborative behavior of the partner firms.

Third, future work might add moderating variables associated with the nature of a firm's alliance activities. For example, the effect of alliance network performance on market performance may depend on the amount of alliance activity or the type of an alliance. Fourth, future work can also extend the focal-firm perspective to dyadic relationships and examine the sharing of partnership gains from the perspective of each company in the relationship. The current study design did not allow for assessment of how a focal firm's actions might affect counteractions from its collaboration partners. Fifth, the present study shares a methodological concern, CMV, with other research in marketing. The potential for common method bias arises when data on the key dependent variable (e.g., market performance) are derived from the same source as the data on important independent variables (e.g., alliance competency). Harman's single-factor test was used to control if a substantial amount of CMV was present in the data. It should be noted that there are several limitations of this technique. Although we can conclude that a single factor did not account for all of the variance in the data, this procedure does nothing to statistically control for method effects. It only assesses the extent to which CMV may be a problem. Independently obtained, objective data on firm performance could alleviate such a concern in future studies. Finally, future work may explore the degree to which additional organizational and/or interfirm variables might strengthen the validity of alliance orientation as a construct worthy of study in marketing. 


\section{APPENDIX A}

\section{Scale Items and Reliabilities}

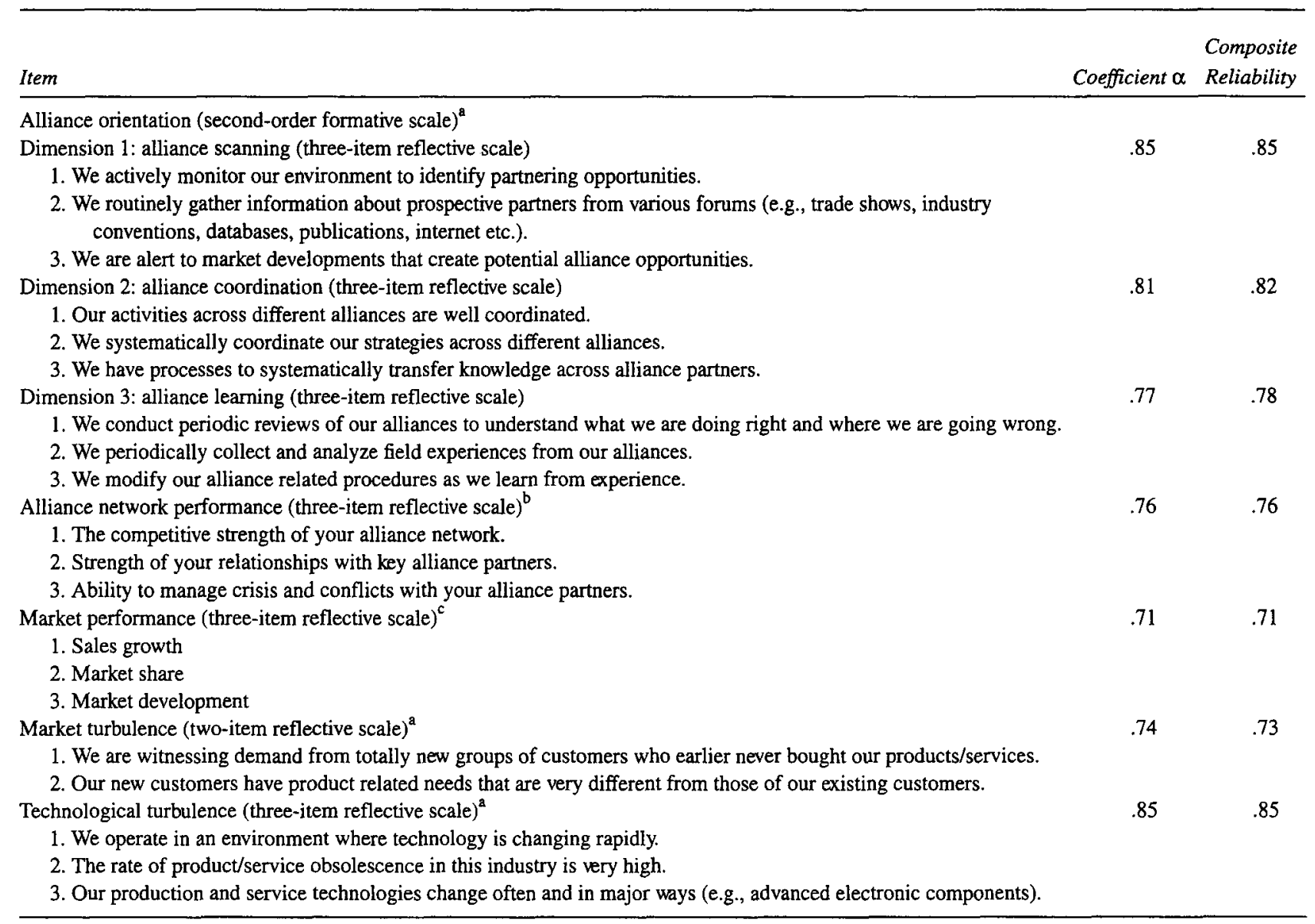

a. The scale anchors were strongly disagree and strongly agree.

b. The scale anchors were very unsatisfactory and very satisfactory.

c. The scale anchors were much worse and much better compared with main competitors.

\section{APPENDIX B \\ Moderating Effect Analysis as Suggested by Mathieu et al. (1992)}

This procedure involves four steps. First, the raw scores of latent variables are centered, and summing the indicators of each of these component variables creates composites for the latent variables. In our work, we developed summated scores for each alliance orientation dimension. These operated as formative indica-tors of each dimension; thus, alliance orientation was represented as a composite of these three indicators (i.e., alliance scanning, alliance coordination, and alliance learning).

Second, these centered scale scores are multiplied to form the latent products (i.e., Alliance Orientation $\times$ Market Turbulence and Alliance Orientation $\times$ Technological Turbulence).

Third, the scale reliabilities (i.e., coefficient $\alpha$ values) are used to fix the relationships between the observed scale scores and their corresponding latent constructs, as well as the error variances for each variable, consistent with the method suggested by Busemeyer and Jones (1983) for testing moderated relationships in latent structural models. Specifically, the $\lambda$ values relating the latent variables to their indicator variables are set equal to the square roots of the reliabilities of alliance orientation, market turbulence, technological turbulence, alliance network performance, and market performance, and the $\theta$ values for each of these observed variables are set equal to the product of its variance and one minus its reliability (Jöreskog and Sörbom 1989). With these values fixed, the additive model, which excludes the latent product variables, is then tested for the purpose of discovering the correlation between the exogenous latent variables (i.e., alliance orientation, market turbulence and technological turbulence).

Finally, the values from the analysis of the additive model are used to compute the reliability for the product terms using the formula from Bohrnstedt and Marwell (1978). This reliability is then used to fix the $\lambda$ values for the path from the latent product to its indicator, and the $\theta$ value for the indicator of the latent product is set equal to the product of its variance and one minus its reliability. 


\section{REFERENCES}

Anand, Bharat N. and Tarun Khanna. 2000. "Do Firms Learn to Create Value? The Case of Alliances." Strategic Management Journal 21 (3): 295-315.

Anderson, James C. and D. W. Gerbing. 1988. "Structural Equation Modeling in Practice: A Review and Recommended Two-Step Approach." Psychological Bulletin 103 (3): 411-423.

—_ Hakan Hakansson, and Jan Johanson. 1994. "Dyadic Business Relationships Within a Business Network Context." Journal of Marketing 58 (4): 1-15.

and James A. Narus. 1990. "A Model of Distributor Firm and Manufacturer Firm Working Partnerships." Journal of Marketing 54 (1): 42-58.

Armstrong, J. Scott and Terry S. Overton. 1977. "Estimating NonResponse Bias in Mail Surveys." Journal of Marketing Research 14 (3): $396-402$

Aulakh, Preet S., Masaaki Kotabe, and Arvind Sahay. 1996. "Trust and Performance in Cross-Border Marketing Partnerships: A Behavioral Approach." Journal of International Business Studies 27 (5): 10051032.

Bagozzi, Richard P., Youjae Yi, and Lynn W. Phillips. 1991. "Assessing Construct Validity in Organizational Research." Administrative Science Quarterly 36 (September): 421-458.

Barney, Jay. 1991. "Firm Resources and Sustained Competitive Advantage." Joumal of Management 17 (1): 99-120.

Baron, Reuben M. and David A. Kenny. 1986. "The Moderator-Mediator Variable Distinction in Social Psychological Research: Conceptual, Strategic, and Statistical Considerations." Journal of Personality and Social Psychology 51 (6): 1173-1182.

Bentler, Peter M. 1995. EQS Structural Equations Program Manual. Los Angeles: Multivariate Software.

Bohrnstedt, G. W. and G. Marwell, 1978. "The Reliability of Products of Two Random Variables." In Sociological Methodology. Ed. K. F. Schuessler. San Francisco: Jossey-Bass, 254-273.

Bollen, Kenneth A. 1989. Structural Equations With Latent Variables. New York: John Wiley.

___ and Richard Lennox. 1991. "Conventional Wisdom on Measurement: A Structural Equation Perspective." Psychological Bulletin 110 (2): $305-314$

Bucklin, Louis P. and Sanjit Sengupta. 1993. "Organizing Successful CoMarketing Alliances." Journal of Marketing 57 (April): 32-46.

Busemeyer, J. R. and L. E. Jones. 1983. "Analysis of Multiplicative Combination Rules When the Causal Variables Measured With Error." Psychological Bulletin 93:549-562.

Chung, Seungwha, Harbir Singh, and Kyungmook Lee. 2000. "Complementarity, Status Similarity and Social Capital as Drivers of Alliance Formation." Strategic Management Joumal 21 (1): 1-22.

Churchill, Gilbert A., Jr. 1979. "A Paradigm for Developing Better Measures of Marketing Constructs." Journal of Marketing Research 16 (1): 64-73.

Dahlstrom, Robert, Kevin M. McNeilly, and Thomas W. Speh. 1996 "Buyer-Seller Relationships in the Procurement of Logistical Ser. vices." Journal of the Academy of Marketing Science 24 (2): 110-124.

Day, George S. 1994. "The Capabilities of Market-Driven Organizations." Journal of Marketing 58 (4): 37-52.

1995. "Advantageous Alliances." Journal of the Academy of Marketing Science 23 (4): 297.

_ and David B. Montgomery. 1999. "Charting New Directions for Marketing." Journal of Marketing 63:3-13.

Diamantopoulos, Adamantios and Heidi M. Winklhofer. 2001. "Index Construction With Formative Indicators: An Alternative to Scale Development." Journal of Marketing Research 38 (2): 269-277.

Doz, Yves L. 1996. "The Evolution of Cooperation in Strategic Alliances: Initial Conditions or Learning Processes?" Strategic Management Journal 17:55-83.

Dwyer, F. Robert, Paul H. Schurr, and Sejo Oh. 1987. "Developing Buyer-Seller Relationships." Journal of Marketing 51 (2): 11-27.

Eisenhardt, Kathleen M. and Jeffrey A. Martin. 2000. "Dynamic Capabilities: What Are They?" Strategic Management Journal 21 (10/11) 1105-1121.
Fornell, Claes and David F. Larcker. 1981. "Evaluating Structural Equation Models With Unobservable Variables and Measurement Error." Journal of Marketing Research 18 (1): 39-50.

Gerbing, David W. and James C. Anderson. 1988. "An Updated Paradigm for Scale Development Incorporating Unidimensionality and Its Assessment." Journal of Marketing Research 25 (2): 186-192.

Geringer, J. Michael. 1991. "Strategic Determinants of Partner Selection Criteria in International Joint Ventures." Journal of International Business Studies 22 (1): 41-62.

Germain, Richard, Cornelia Dröge, and Patricia Daugherty. 1994. "The Effect of Just-in-Time Selling on Organizational Structure: An Empirical Investigation." Journal of Marketing Research 31 (4): 471. 483.

Gulati, Ranjay. 1998. "Alliances and Networks." Strategic Management Joumal 19 (4): 293-317.

- 1999. "Network Location and Learning: The Influence of Network Resources and Firm Capabilities on Alliance Formation." Strategic Management Journal 20 (5): 397-420.

___. Nitin Nohria, and Akbar Zaheer. 2000. "Strategic Networks." Strategic Management Journal 21 (3): 203.

Gundlach, Greg T. and Ernest R. Cadotte. 1994. "Exchange Interdependence and Interfirm Interaction: Research in a Simulated Channel Setting." Journal of Marketing Research 31 (November): 516-532.

Gupta, Anil K. and V. Govindarajan. 1984. "Business Unit Strategy, Managerial Characteristics, and Business Unit Effectiveness at Strategy Implementation." Academy of Management Journal 27 (1): $25-41$.

Hejde, Jan B. and George John. 1990. "Alliances in Industrial Purchasing: The Determinants of Joint Action in Buyer-Supplier Relationships." Journal of Marketing Research 27 (1): 24-36.

Hite, Julie M. and William S. Hesterly. 2001. "The Evolution of Firm Networks: From Emergence to Early Growth of the Firm." Strategic Management Journal 22 (3): 275-286.

Hu, Li-tze and Peter Bentler 1999. "Cutoff Criteria for Fit Indexes in Covariance Structure Analysis: Conventional Criteria Versus New Alternatives." Structural Equation Modeling 6 (1): 1-55.

Huber, George P. 1991. "Organizational Leaming: The Contributing Processes and the Literatures." Organization Science 2 (1): 88-115.

Jap, Sandy D. 1999. "Pie-Expansion Efforts: Collaboration Processes in Buyer-Supplier Relationships." Journal of Marketing Research 36 (4): 461-475.

and Shankar Ganesan. 2000. "Control Mechanisms and the Relationship Life Cycle: Implications for Safeguarding Specific Investments and Developing Commitment." Journal of Marketing Research 37 (2): 227-245.

Jarvis, Cheryl Burke, Scott B. Mackenzie, and Philip M. Podsakoff. 2003. "A Critical Review of Construct Indicators and Measurement Model Misspecification in Marketing and Consumer Research." Journal of Consumer Research 30 (2): 199-218.

Jaworski, Bernard J. and Ajay K. Kohli. 1993. "Market Orientation: Antecedents and Consequences." Journal of Marketing 57 (3): 53-70.

Jöreskog, Karl G. and Dag Sörbom. 1989. LISREL VII: User's Reference Guide. Mooresville, IN: Scientific Software.

Khanna, Tarun. 1998. “The Scope of Alliances." Organization Science 9 (3): $340-355$

Kohli, A jay K. and Bernard J. Jaworski. 1990. "Market Orientation: The Construct, Research Propositions, and Managerial Implications." Journal of Marketing 54 (2): 1-18.

Korsgaard, M. Audrey and Loriann Roberson. 1995. "Procedural Justice in Performance Evaluation-The Role of Instrumental and Noninstrumental Voice in Performance-Appraisal Discussions." Journal of Management 21:657-669.

Kumar, Nirmalya, Lisa K. Scheer, and J.B.E.M. Steenkamp. 1995. "The Effects of Perceived Interdependence on Dealer Attitudes." Journal of Marketing Research 32 (August): 348-356.

Lambe, Jay C., Robert E. Spekman, and Shelby D. Hunt. 2002. "Alliance Competence, Resources, and Alliance Success: Conceptualization, Measurement, and Initial Test." Journal of the Academy of Marketing Science 30 (2): 141-158.

_ C. Michael Wittmann, and Robert E. Spekman. 2001. "Social Exchange Theory and Research on Business-to-Business Relational Exchange." Journal of Business-to-Business Marketing 8 (3): 1-36. 
Larson, Andrea. 1992. "Network Dyads in Entrepreneurial Settings: A Study of the Governance of Exchange Relationships." Administrative Science Quarterly 37 (1): 76-104.

Leonard-Barton, Dorothy. 1992. "Core Capabilities and Core Rigidities: A Paradox in Managing New Product Development." Strategic Man. agement Journal 13 (8): 111-125.

$\mathrm{Li}$, Tiger and Roger J. Calantone. 1998. "The Impact of Market Knowledge Competence on New Product Advantage: Conceptualization and Empirical Examination." Journal of Marketing 62 (4): 13-29.

Lippman, S. A. and R. P. Rumelt. 1982. "Uncertain Imitability: An Analysis of Interfirm Differences in Efficiency Under Competition." Bell Journal of Economics 13 (2): 418-438.

Lorenzoni, Gianni and Andrea Lipparini 1999. "The Leveraging of Interfirm Relationships as a Distinctive Organizational Capability: A Longitudinal Study." Strategic Management Journal 20 (4): 317-338.

Lyles, Marjorie A. 1988. "Learning Among Joint Venture Sophisticated Firms." Management International Review 28 (4): 85-97.

Mathieu, John E., Scott I. Tannenbaum, and Eduardo Salas. 1992. "Influences of Individual and Situational Characteristics on Measures Training Effectiveness." Academy of Management Journal 35:828847.

Morgan, Robert M. and Shelby D. Hunt. 1994. "The Commitment-Trust Theory of Relationship Marketing." Journal of Marketing 58 (July): 20-38.

Mossholder, Kevin W., Nathan Bennett, Edward R. Kemery, and Mark A. Wesolowski. 1998. "Relationships Between Bases of Power and Work Reactions: The Mediational Role of Procedural Justice." Journal of Organizational Behavior 16:127-142.

Narayandas, Das and Kasturi Rangan. 2004. "Building and Sustaining Buyer-Seller Relationships in Mature Industrial Markets." Journal of Marketing 68 (July): 63-77.

Narver, John C. and Stanley F. Slater. 1990. "The Effect of a Market Orientation on Business Profitability." Journal of Marketing 54 (4): 20-35.

Nelson, Richard R. and Sidney G. Winter. 1982. An Evolutionary Theory of Economic Change. Cambridge, MA: Belknap.

Noda, Tomo and David J. Collis. 2001. "The Evolution of Intraindustry Firm Heterogeneity: Insights From a Process Study." Academy of Management Journal 44 (4): 897-926.

Nunnally, Jum C. 1978. Psychometric Theory. New York: McGraw-Hill.

Podsakoff, Philip M., Scott B. Mackenzie, Jeong-Yeon Lee, and Nathan P. Podsakoff. 2003. "Common Method Bias in Behavioral Research: A Critical Review of the Literature and Recommended Remedies." Journal of Applied Psychology 88 (5): 879-903.

Prahalad, C. K. and Gary Hamel. 1990. "The Core Competence of the Corporation." Harvard Business Review 68 (3): 79-91.

Rindfleisch, Aric and Christine Moorman. 2001. "The Acquisition and Utilization of Information in New Product Alliances: A Strength-ofTies Perspective." Joumal of Marketing 65 (April): 1-18.

Sarkar, M. B., Raj Echambadi, S. Tamer Cavusgil, and Preet S. Aulakh. 2001. "The Influence of Complementarity, Compatibility, and Relationship Capital on Alliance Performance." Journal of the Academy of Marketing Science 29 (4): 358-373.

Simonin, Bernard L. 1997. "The Importance of Collaborative KnowHow: An Empirical Test of the Learning Organization." Academy of Management Joumal 40 (5): 1150-1174.

Sinkula, James M. 1994. "Market Information Processing and Organizational Learning." Journal of Marketing 58 (1): 35-45.

Sivadas, Eugene and F. Robert Dwyer 2000. "An Examination of Organizational Factors Influencing New Product Success in Internal and Alliance-Based Processes." Joumal of Marketing 64 (January): 3149.

Slater, Stanley F. and John C. Narver. 1994. "Does Competitive Environment Moderate the Market Orientation-Performance Relationship?" Joumal of Marketing 58 (1): 46-55.

Song, Michael, Cornelia Dröge, Sangphet Hanvanich, and Roger J. Calantone. 2005. "Marketing and Technology Resource Comple- mentarity: An Analysis of Their Interaction Effect in Two Environmental Contexts." Strategic Management Journal 26 (3): 259-276.

Teece, David J., Gary Pisano, and Amy Shuen. 1997. "Dynamic Capabilities and Strategic Management." Strategic Management Journal 18 (7): 509-533.

Tsai, Wenpin. 2000. "Social Capital, Strategic Relatedness and the Formation of Intraorganizational Linkages." Strategic Management Journal 21 (9): 925-939.

Uzzi, Brian. 1996. "The Sources and Consequences of Embeddedness for the Economic Performance of Organizations: The Network Effect." American Sociological Review 61 (4): 674-698.

Varadarajan, P. Rajan and Margaret H. Cunningham. 1995. "Strategic Alliances: A Synthesis of Conceptual Foundations." Journal of the Academy of Marketing Science 23 (4): 282.

Venkatraman, N. and Vasudevan Ramanujam. 1986. "Measurement of Business Performance in Strategy Research: A Comparison of Approaches." Academy of Management Review 11 (4): 801-814.

Webster, Frederick E., Jr. 1992. "The Changing Role of Marketing in the Corporation." Joumal of Marketing 56 (4): 1-17.

Weitz, Barton A. and Sandy D. Jap. 1995. "Relationship Marketing and Distribution Channels." Journal of the Academy of Marketing Science 23 (4): 305.

Wind, Jerry and Vijay Mahajan. 1997. "Issues and Opportunities in New Product Development: An Introduction to the Special Issue." Journal of Marketing Research 34 (1): 1-12.

Zollo, Maurizio and Sidney G. Winter. 2002. "Deliberate Learning and the Evolution of Dynamic Capabilities." Organization Science 13 (3): 339-353.

\section{ABOUT THE AUTHORS}

Destan Kandemir (kandemir@msn.edu) is a research associate in Center for International Business Education and Research at Michigan State University. She earned her PhD in marketing and international business from Michigan State University. Her articles have appeared in the Journal of Business and Industrial Marketing, Industrial Marketing Management, the Journal of International Marketing, and the Journal of Management. Her research interests include firm resources and capabilities, market-oriented knowledge management, and global alliance management.

Attila Yaprak (attila.yaprak@wayne.edu) is a professor of marketing and international business at Wayne State University. He received his $\mathrm{PhD}$ from Georgia State University. His research interests include cross-national consumer behavior, global marketing strategy, and international alliances. His research has appeared in the Journal of International Business Studies, the Journal of International Marketing, the Journal of Business Research, and Political Psychology, among others.

S. Tamer Cavusgil (cavusgil@msu.edu) is University Distinguished Faculty and the John W. Byington Endowed Chair in Global Marketing in the Department of Marketing and Supply Chain Management, Eli Broad Graduate School of Management, Michigan State University. 